\title{
THEORIES OF TECHNOLOGICAL PROGRESS AND THE BRITISH TEXTILE INDUSTRY FROM KAY TO CARTWRIGHT
}

\author{
P. K. O'BRIEN, T. GRIFFITHS \\ and P. A. HUNT \\ Institute of Historical Research (London) \\ and University of Edinburgh
}

\begin{abstract}
RESUMEN
La industria textil británica continúa en el centro del debate sobre la revolución industrial. Las innovaciones técnicas en el periodo produjeron una aceleración extraordinaria del crecimiento del output y una considerable reducción de los precios de los tejidos. En este trabajo presentamos un estudio de la comunidad de los inventores responsables de la transformación tecnológica, lo que nos permite alcanzar una serie de conclusiones nuevas sobre el ritmo y dirección de la actividad innovadora durante la revolución industrial.
\end{abstract}

\begin{abstract}
The cotton textile industry remains central to all accounts of the first industrial rev. olution. Innovations in this period precipitated an extraordinary acceleration in the growth of output and a steep decline in the cost of producing all varieties of cloth. In this paper we outline an explanation through an analysis of the community of inventors responsable for the technological transformation, which enables us to offer some new generalizations of the pace and pattern of the inventive activity in this period.
\end{abstract}

\section{INTRODUCTION}

The cotton textile industry remains central to accounts of the first industrial revolution. Indeed, interpretations now current confirm the need to rec- 
onsider the sources of technological progress in that sector, more especially of those «prototype» or «macro inventions» which emerged between John Kay's patent for the flying shuttle in 1733 and Edmund Cartwright's first powerloom patent in 1785. Innovations in this period precipitated an extraordinary acceleration in the growth of output and a steep decline in the cost of producing all varieties of cloth. This «story», although familiar, has never been adequately explained by historians, who lack a general theory capable of accounting for the major breakthroughs in textile technology that occurred over the eighteenth century '. Paradoxically, the need for such a theory has been rendered even more important by recent analyses which have sought to marginalize the role of new technology and which have encouraged attempts to expunge the whole notion of an «Industrial Revolution» from «sensible historical discourse» ${ }^{2}$.

Interest in the British experience of industrialization has recently centred on the research of quantifiers, working within orthodox parameters of macroeconomic analysis. It is unnecessary, in the context of this essay, to give extended consideration to the attempts of cliometricians to mould and calibrate imperfect data into a growth accounting framework, in order to relate increases in national output to long-term changes in the inputs of land, labour and capital. Nevertheless, their conclusions are clear ${ }^{3}$.

Firstly, on all the indicators used to measure the pace and pattern of British economic growth between 1688 and 1851, the first industrial revolution emerges as a slower and less dramatic discontinuity than was previously thought. As a result, several historians have been tempted to dismiss it as a myth or a misnamed episode in European economic and technological history. If we examine the reconstituted data now available to measure the pace of economic change in Britain (i.e. growth rates in real per capita income, industrial output per head, and in the productivity of labour employed in manufacturing and agriculture), then the industrial revolution as a widely-diffused national event does not come on stream until well into the nineteenth century, several decades later than several classic accounts suggested 4 . If, however, the longer view is taken, comparing estimated rates of change for the first half of the eighteenth century with those for the second quarter of the nineteenth century, then marked discontinuities, more especially in industrial output, re-

1 D. S. Landes (1969), pp. 80-88; T. S. Ashton (1948a), pp. 58-93, 216; N. Rosenberg (1982). pp. $4 \cdot 27$.

2 P.K. O'Brien (1993).

3. Berg and P. Hudson (1992); N. F. R. Crafts and C. K. Harley (1992).

+ Ashton (1948a); P. A. Dane and W. A. Cole (1962). 
main inescapable. Contemporaries needed no convincing that Britain's society and economy had undergone profound changes which appeared set to continue at an accelerated rate. Foreign visitors readily concurred; they knew a successful industrial economy when they saw one and acknowledged the need for their own countries to «catch up» '. Secondly, the initial phases of the industrial revolution are now seen to have been «extensive» rather than «intensive». A high proportion of the increment to national output before $1825 \mathrm{can}$ be attributed to the employment of more labour and capital inputs, so that increases in factor productivity are downplayed. Thirdly, it is observed that where and when productivity improvements occurred, they were located in only a few sectors. Within industry, the impact of technological breakthroughs and improvements was confined, before the second quarter of the nineteenth century, to basic metallurgy and to textiles, above all to cotton. As late as the 1830 s, the mechanization of cotton production and its concentration into steam-powered urban factories, represented a paradigm for other industries to emulate . The industrial revolution emerges as an example of «unbalanced growth" ${ }^{7}$.

Viewed thus, this interpretation of the first industrial revolution presents a familiar narrative, in which textiles in general, and cotton in particular, are presented as exemplary cases of early mechanization ${ }^{8}$. Of course, such an interpretation is highly contested, especially by historians whose research into regions, proto-industrialization and transformations in the organization of traditional work practices and in attitudes to work itself, lead them to argue for a more broadly-based sequence of change ". The debate thus provoked is likely to continue, but for the purposes of this essay the results of cliometric analyses provide ample justification for focusing again on textiles and on the sequence of discoveries from Kay to Cartwright. In many respects, the rapid and pervasive industrial growth of the late-Hanoverian and Victorian periods can be seen as an elaboration of technological knowledge brought to maturity somewhat earlier within a single leading sector. Thus, if historians could offer a general explanation for the inventions and improvements that transformed the making of cloth over the century following the patenting of Kay's flying shuttle, they might be on the way to communicating an understanding of the

\footnotetext{
S. K. O'Brien and C. Keyder (1978), pp. 18.68.

R. Samuel (1977); P. Hudson (1992). pp. 2.14

N. F. R. Crafts $(1985)$.

* P. Mantoux (1964).

Berg and Hudson (1992); J. de Vries (1994).
} 
prime mover behind the first wave of British and European industrialization ${ }^{1 !}$.

In this paper, a possible outline for such an explanation is sought through an analysis of the nature of textile invention from the Restoration to the midnineteenth century and of the community of inventors responsible for the technological transformations which occurred in this period. The findings generated by research into the backgrounds of some 2,500 individuals allow some assessment to be made of existing theories of technological change and enable us to offer some middle-range generalizations of our own concerning the pace and pattern of inventive activity.

\section{THEORETICAL PERSPECTIVES ON TECHNICAL CHANGE}

Textile innovation comprehended new techniques and processes involved in the transformation of agricultural raw materials (wool, flax, hemp, silk and cotton) into finished (bleached, dyed, and printed) cloth. The changes introduced comprised: new products or variations on old products sold to consumers; processes designed to raise the quality of output, while holding the overall cost of inputs constant; or techniques which lowered production costs by reducing the quantities of capital, labour, time, raw materials, energy, etc., per unit of output. As will be seen later, the relative importance of each of these categories varied markedly over time. A comprehensive list of inventions between 1688 and 1850 would be enormous. Unfortunately, only a fraction of the total flow of technological improvements introduced in that period is recoverable from the sources. These include: patent specifications; the records of institutions which sponsored the search for technological advances; as well as numerous contemporary and secondary accounts of inventive activity, both successful and abortive. The surviving data suffice to allow taxonomies to be imposed, differentiating «product «from «process» innovations and categorizing inventions according to the stage in the production process that was affected. More problematically, macro inventions have been distinguished from improvements which, by adapting protoytpe machines, processes or products, sought to bring them into efficient day-to-day use. As we study the series of major inventions and improvements which were to revolutionize all processes involved in the cloth manufacture, it is apparent that they emerged discontinuously, even haphazardly, over time. At the close of this sequence, around the

\footnotetext{
16. M. Dintenfass (1992).
} 
middle of the nineteenth century, textile production had been transformed from a handicraft proto-manufacture, using some machinery and water power, into a mechanized, steam- powered, factory-based urban industry ${ }^{11}$. In the context of the millenia over which craftsmen and women had been employed in making cloth, this period of radical change is so short, the transformation within and across all stages of production so rapid, and the focus of change so geographically concentrated, that the «British» revolution in textiles has, with reason, been recognized as a critical episode in the history of technology.

The question remains, whether this process can be explained in a general and communicable way. Neither narrative accounts, dealing with each innovation in turn, nor overarching theories drawing on economic or sociological frames of reference would appear to fit the bill ${ }^{12}$. For example, objections may be raised against both demand-led or supply-induced theories of technological change, where the incentive to invent is seen to flow from consumer needs and expenditures or from bottlenecks and shortages experienced by producers. Potentially profitable inventions were always in demand, once the cloth industries of Western Europe became involved in competitive production for home and foreign markets, while growing shortages of labour, raw materials, and other inputs were neither sufficient nor necessary to encourage businessmen and merchants to promote the search for innovations 13 .

What is more, neither demand nor supply theories can be tested empirically for the period which witnessed the transformation of - British textile production. It is not clear that demand pressures from consumers for more novel and/or cheaper forms of cloth were any greater on British producers than on their Dutch and French counterparts. Nor is it clear that such pressures intensified prior to the upswing in the pace of technological progress in the second half of the eighteenth century. Why, it might legitimately be asked, did the spinning jenny and the water frame appear in the 1760 s and not earlier, when the level of demand for cheaper yarn was probably just as buoyant? Furthermore, if demand-pull were a decisive influence on the pace and timing of innovation why was there such a pronounced lag between the appearance of the major mechanical breakthroughs in weaving and their subsequent improvement and diffusion?

11 I. Inkster (1991), pp. 1-13, 32-88; C. Singer, E. I. Holmyard, A. R. Hall, and T. I. Williams 1957), pp. 151-205; Singer. Holmyard, Hall, and Williams (1988), pp. 230-57, 277.327: J. Mokyr
(1990).

12 Rosenberg (1982), pp. 4-27; W. E. Bijker, T. P. Hughes, and T. J. Pinch (1987).

${ }^{13}$ P. K. O'Brien (1991); Mokyr (1990), pp. 57-112, 151-92, 239.300. 
Demand-led theories of industrial growth and innovation have recently been revived by historians concerned to trace the rise of material culture and a consumer society in the seventeenth and eighteenth centuries. Proponents of the aconsumer revolution» hypothesis argue that, from the Restoration onwards, social, cultural, and political changes worked to alter propensities to consume across England, with the result that the home market became altogether more hospitable to merchants and industrialists seeking to persuade households to buy a greater variety and volume of textiles and other goods ${ }^{14}$. The new cultural history of European materialism is concerned to emphasize that there was a demand side to economic (and thus to technological) progress and that demand was driven by more than falling prices and rising incomes. Economic growth certainly required populations not only able but willing and eager to consume the products of industry. In turn, consumer enthusiasm depended upon the readiness of households to: allow novel material goods into private domains; convert leisure into work to spend on the «superfluities» of the moment; sustain levels of consumption in the face of adverse changes in their real incomes; emulate the consumption patterns of neighbours and betters; and fashion their identities through conspicuous consumption. Such propensities, the argument proceeds, were culturally ordered and changed slowly through time ${ }^{15}$.

The problem with the erise of material culturen thesis is that it appears impossible to isolate changes that can be identified as peculiarly British or to date any discontinuity in consumer behaviour that would be sufficiently powerful to sustain the pressure of demand at a level necessary to promote a continuous stream of innovation. The thesis has its place in the history of the industrial revolution, but compared with the many supply-side changes which operated to widen markets for textiles, it is difficult to accord cultural developments, themselves in part economically conditioned, much «autonomous» weight. The rise of material culture coincided with: the integration of the market through investment in transportation and improved networks for the distribution of manufactured goods; changes in imperial and foreign policies which helped to secure markets overseas; the growth in agricultural productivity which limited the proportion of income that households had to devote to expenditure on basic foodstuffs; rising rates of investment in urban construction and industry; and, above all, conscious attempts by cloth producers to cajole consumers into buying more through an entirely traditional process of

14 C. Mukerji (1983), pp. 166-261: C. Campbell (1987); N. McKendrick, J. Brewer, and J. H. Plumb (1982); J. Mokyr (1977); A. Y. B. Schachar (1984); E. Gilboy (1967).

15 C. Shammas (1990); B. Lemire (1991); J. Brewer and R. S. Porter (1993). 
product differentiation. Cultural changes may have had an important influence on demand, but they need to be specified, dated and related more clearly to innovations in production ".

It is no less difficult to link supply-side models to the pace and pattern of technological change over the eighteenth century. Mercantilist writers of the period made repeated complaints about the high level of English wages and about the idleness, insubordination and irrational preference for leisure dis. played by native workers. However, the data required to subject such state. ments to close empirical analysis and to demonstrate that the search for labour- saving machinery became more powerful as the period progressed are lacking ${ }^{1}$. At the same time that calls were made to utilize under-employed pauper, female and child labour, putting it to work on officially-sponsored spinning schemes, concern was being expressed about under-employment and unemployment among adult males, more especially after population growth accelerated after mid- century 18 .

Further problems may be cited. Firstly, at a national level, the case for increasingly inelastic supplies of labour available for industrial work is less than compelling, given that the acceleration in population growth occurred both earlier and faster in England than on the Continent. Secondly, food price increases from mid-century would presumably have compelled the previously «idle» to work harder in order to maintain their own and their families» consumption levels ${ }^{19}$. Thirdly, labour-market demarcations based upon skill and gender broke down, enabling «reserve armies» of women, children and those from the Hanoverian State's Celtic fringe to move into industrial employment. Finally, all the evidence suggests that textile innovations diffused more rapidly in traditionally low-wage regions (e.g., in Lancashire and Yorkshire before Wiltshire and East Anglia) 20.

An important addition to our knowledge of eighteenth-century labour markets could be provided by research which aimed to reconstruct local matrices of demand and supply for the specialized labour employed in the production of particular fabrics. Just as the final product of the industry, cloth, differed considerably in nature, so the labour and skills required to manipulate its constituent fibres were diverse. What can be said at present is that the im-

in T. Griffiths, P. A. Hunt, and P. K. O'Brien (1992).

1 An extensive search of primary and secondary sources led us to conclude, reluctantly, that nothing definitive can be said about eighteenth-century textile wage rates.

in T. W. Hutchison (1988); T. E. Gregory (1921), pp. 40.44; A. W. Coats (1958.9); Coats 1976), pp. 108.9

${ }^{14}$ P. K. O'Brien (1985); De Vries $(1994)$

2" E. H. Hunt and F. W. Botham (1987); E. H. Hunt (1986), p. 952 
petus to innovation came as much from concerns to upgrade quality and develop contingent skills among local workforces as from the need to circumvent any increase in real product wages ${ }^{21}$.

Other inducements mechanisms are equally difficult to document, particularly the ever-popular «challenge and response» model. This explains the sequence and timing of innovations in terms of imbalances, whereby the diffusion of a new technique in one stage of the production process sets up pressures for a response both up and (more especially) downstream, to meet intensified demands for inputs or more elastic and cheaper supplies of outputs. The most frequently cited example is Kay's shuttle, which is said to have doubled the productivity of weavers, creating an enhanced demand for yarn which could only be satisfied by major spinning innovations. In turn, the new machines of Hargreaves, Arkwright and Crompton produced a surfeit of yarn, prompting a search for effective power looms, which was only effectively resolved some five decades later by Richard Roberts ${ }^{22}$. Apart from the often protracted lapses of time between challenge and response, which need to be explained, there is no evidence in the statistics on recorded invention over the eighteenth century that innovation clustered around particular production stages at clearly defined points in time. It should also be noted that Kay's shuttle, which plays such a pivotal role in the story, cannot be explained either in terms of an upstream response to developments in the finishing of cloth or of the inducement provided by enhanced access to cheaper supplies of yarn. More importantly, Kay's invention was simply too circumscribed in its effects to be linked convincingly to the wave of spinning innovations and improvements in the third quarter of the eighteenth century ${ }^{23}$.

Sources are, however, available which enable us to move beyond the rather negative task of pointing up shortcomings in the theoretical assumptions underlying textbook accounts of technological change. Published data on patents, the records of official and semi-official agencies in England, Scotland and Ireland, which promoted innovations in textile production, along with material contained in industrial histories provide the material from which the pace and

2: E. Richards (1974); D. Bythell (1969), pp. 42.65; E. Kerridge (1985), pp. 235.8; E. Baines 11803): J. Anstic (1803).

22 Landes (1969), pp. 41.88; Mantoux (1964), pp. 208.9. 239; T. Sutcliffe (1843); Edwards (1967), p. 3; the durable nature of the achallenge and response» thesis is indicated by the latest overview of technological innovation in the textile industry, which repeats it uncritically, G. Tim. mins (1996), p. 39 .

"For the limited effects of Kay's shutte on narrow goods, described in Kay's own sub. mission to the Society for the Encouragement of Arts, Manufactures and Commerce, see A. Paul. inyi (1986), p. 154; Sir H. T. Wood (1911-12), pp. 83.4. 
pattern of inventive activity may be assessed, while biographical information on the collectivity of inventors and improvers active in textiles between the mid- seventeenth and mid-nineteenth centuries, enables us to reconstruct the social, religious and educational milieux which gave rise to technical change.

\section{PATTERNS OF TECHNOLOGICAL CHANGE}

Using evidence culled primarily from patent statistics, cliometricians and economists are disposed to aggregate recorded inventions into an index, purporting to represent annual and cyclical variations in the volume of technological change within particular industries or across national economies. Such an index would be of undoubted utility for historians, but, save for entirely limited purposes, no reliable indicator can be constructed, since recorded innovations represent an unknown and possibly variable proportion of changes in the total flow of invention ${ }^{24}$. Even those innovations for which we have some record cannot be aggregated without some system of weighting to account for variations in their economic and technological significance, otherwise Hargreaves» spinning jenny would be accorded the same importance as Peter Vallotton's patent for the manufacture of hosiery pieces adapted for the wear of persons afflicted with rheumatism, gout, etc., which was taken out in the same year. Finally, changes in the propensity to patent and in the commer. cial viability of patented and non-patented inventions could seriously compromise the comparability of recorded totals over time ${ }^{25}$.

No precise index of technological change can be constructed from simple aggregative methods alone. However, information is available within patent specifications and other descriptions of inventions which can be tabulated to expose broad changes in the pattern of inventive activity over time. Furthermore, the claims advanced by inventors for the benefits anticipated from their discoveries reveal important variations in the nature of inventive activity ${ }^{26}$. If it remains impossible to identify precise discontinuities, some impression of long-term changes in the scale of innovation can be captured from the figures. Taking patents alone, a series unaffected by institutional initiatives through the

24 (iriffiths, Hunt and O'Brien (1992).

${ }^{25}$ For a recent discussion, sec Griliches (1990); J. Schmookler (1966); Schmookler (1962), pp. 78.83: K. L. Sokoloff (1988); R. I. Sullivan (1989); Sullivan (1990); C. Macleod (1988), pp. 2-7. 115.
144.57.

26 Griffiths, Hunt and O'Brien (1992). 
period, the total registered between the late-seventeenth and the mid-nineteen h centuries changed as follows:

TABLE 1

Numbers of Patents and Textile Patents, 1675-1849

\begin{tabular}{|c|c|c|}
\hline Period & Total Patents & Textile Patents \\
\hline 1675.99. & 187 & 34 \\
\hline $1700 \cdot 24 \ldots$ & 109 & 18 \\
\hline 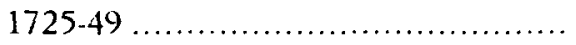 & 178 & 34 \\
\hline 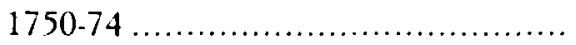 & 442 & 75 \\
\hline 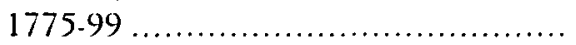 & 1,273 & 236 \\
\hline $1800-24 \ldots \ldots \ldots \ldots$ & 2,697 & 458 \\
\hline $1825.49 \ldots \ldots \ldots \ldots$ & 7,848 & 1,509 \\
\hline
\end{tabular}

Sources: B. Woodcroft (1854); A. A. Gomme (1932-3); D.R. Jamieson (1969).

Particular turning points, based on changes in annual figures, remain difficult to verify ${ }^{27}$. However, the figures can be advanced to suggest that the volume of innovative activity increased significantly and constituted a critical component of British economic growth over this period ${ }^{28}$. Other plausible inferences have been derived from the patent statistics. For example, the proportion of "professional» patentees, who Dutton defined as those registering two or more innovations and whose claims to intellectual property rights encompassed more than one industry, increased from $28 \%$ in 1751.60 to $50 \%$ in $1841.50^{29}$.

The same long-term trend towards the professionalization of inventive activity can be detected in textiles, which accounted for by far the largest proportion of patents registered for any one sector in the period to 1850 . There was a predictable tendency for inventors increasingly to emanate from the "new" and rising areas of cloth production, in the midlands and north of England. Although the addresses of agents representing inventors complicate attempts at geographical reconstruction, the relative decline of London, East Anglia and southern counties as centres of technological creativity is apparent,

2: For a contrary view, see Sullivan (1989) and (1990). The debate is continued in Sullivan (1995) and O'Brien, Griffiths and Hunt (1995).

2* T. S. Astiton (1948b).

${ }^{29}$ H. I. Dutton (1984), p. 114. 
more especially after 1800 . Shortcomings in the sources dictate that, while the increasing specialization of inventive activity may be inferred, it cannot be demonstrated statistically. Competitive pressures obliged patentees to insist that their innovations, rather than being fabric specific, could apply equally well to the broader range of textile fibres. Nevertheless, the rise of specialist manufacturers and machine makers meant that the process of innovation became progressively more endogenous to particular sectors of the industry.

From approximately 1800 onwards, technological change in textiles proceeded in a manner altogether more explicable in terms of conventional economic analysis. Innovation became increasingly dominated by improvements to and elaborations on machines and processes that had emerged in prototype form several decades earlier. The problem remains: why were so many of those prototype inventions British both in their conception and in their early devel. opment?

\section{PATTERN OF TEXTILE INNOVATION, 1660-1850}

Any attempt to address that broad question should be prefaced by the general observation that economies containing industries which had attained a certain level of maturity and scale of output were more likely to generate innovations than those with infant industries alone. By the early eighteenth century, Britain's productive capability included all major variations of cloth, finished and sold in a wide variety of qualities and finishes. A comparative advantage in the production of woollen cloths was long established. In addition to that, in the half century or so following the Restoration of the monarchy, silk weaving and finishing was established in Kent and London, coarse linens were manufactured with government assistance in Ireland and Scotland, while fustian became a Lancastrian speciality. A level of production and technical sophistication had been achieved, from which British manufacturers could emulate most varieties of foreign cloths, absorb new technologies, and generate a succession of indigenous innovations ${ }^{30}$.

In the hundred years from 1660, the technical progress which propelled the British textile industry on to higher and more variegated levels of output consisted overwhelmingly of product innovations-cloths fabricated from new mixes of yarn and finished in novel ways to render them more attractive to domestic and foreign consumers. This pattern of traditional or "Smithian» growth

31 C. (j. A. Clay (1984); D. C. Coleman (1977); Kerridge (1985); E. Baines 11835 ). 
was both a response to and a factor promoting the widening of markets at home and abroad. By such means, British textile production had, by mid-century, attained a level from which fundamental technological breakthroughs became increasingly likely. Product innovation would remain important, but from 1760 a wave of macro inventions transformed the process of cotton production. A period of improvement and diffusion followed, approximately from the $1790 \mathrm{~s}$, during which the commercial potential of several of the prototype discoveries was realised. This latter phase coincided with a significant shift in the nature of invention, away from improvements to the final product and towards the achievement of factor savings ${ }^{31}$. With the exception of some important developments in the bleaching and dyeing processes, virtually the entire body of advanced technology which transformed textile production in the period from 1760 was initiated by British inventors and improved by British mechanics to the point at which it could be exploited commercially by British businessmen. The task remains to account for the extensive range of prototype discoveries (power driven machinery, new preparatory and finishing techniques, factory modes of organization, and the continuing proliferation of different types of cloth) which came on stream in such a short period, relative to the long history of this industry.

In attempting to deal with this central problem in economic and technological history, it must be emphasized that the critical early breakthroughs in textile production were concentrated around one fabric, namely cotton. The techniques and processes developed there were then adapted and diffused across the woollen and linen manufactures. If this argument tends to oversimplify a complex process of technological interaction across sectors, it does at least serve to specify the problem more precisely: why inventive activity centred on the cotton industry and the British cotton industry in particular.

A partial answer to the first point may be found in the tensile properties of cotton fibres, which rendered them capable of withstanding the strains imposed by both mechanical spinning and powered weaving. The resulting cloth also proved to be adaptable to the new techniques for bleaching, printing, and dyeing which were introduced towards the end of the eighteenth century ${ }^{32}$. Economic forces also had a role to play. From the 1760 s onwards, greater elasticity in the supply of raw cotton, relative to that of hemp, flax, wool and silk, enhanced incentives to allocate resources to the search for improved products and technologies which utilized cotton fibres "3.

3 Griffiths, Hunt and O'Brien (19921, pp. 892-3

3. Baines (1835); A. P. Wadsworth and J. de L. Mann (1931); Edwards (1967).

14 B. Solow (1991). Concern among Lancastrian fustian manufacturers over the escalating 
Britain's lead in the development of mechanized cotton production also owed something to political factors. The major impetus behind the growth of a substantial domestic market for cotton cloth was provided by trade with India. Berween 1660 and 1700, rapidly increasing imports of Indian fabrics, especially in printed form, demonstrated the potential extent of British demand for "new' calicoes, muslins, and nanqueens. Lobbied by established textile manufacturing interests, Parliament (in contrast to governments on the Continent) legislated first to curtail and then to exclude Asian cottons from the domestic market. The ban came into operation in 1722. By then, the English taste for cotton cloth was well established and the potential for mixing cotton yarns with yarn spun from flax and other fibres was fully realized. Under a protective regime, a process of import substitution was energetically pursued. Political and economic circumstances, by encouraging experiments with the mixing of cotton with other fibres, provided the essential foundation for the emergence of an indigenous cotton manufacture in England several decades before a similar capability developed on the Continent. There, policies were pursued which proved to be either too restrictive (French) or too laissez-faire (Dutch) to stimulate native enterprise to such profitable ends ${ }^{34}$.

Political economy thus helps to explain how and why an embryo cotton industry had, by the mid-eighteenth century, developed to a point from which accelerated growth driven by radical technological change seemed ever more probable. However, the timing of individual inventions and their subsequent development to the point of commercial viability continue to defy precise explanation.

\section{TECHNOLOGICAL CHANGE: THE EVIDENCE OF PROSOPOGRAPHY}

In an attempt to resolve this problem, we undertook an investigation into the process of human capital formation. Information was sought on inventors, improvers and promoters of innovation who were active in textiles during the three phases of growth identified earlier. Particular attention was paid to their social status at birth, their education, religion, and scientific background, to estimate how far they might be said to have constituted a distinctive inventive community, identifiably different from the population at large. If such a collec-

\footnotetext{
cost of imports of linen yarn from Ireland was evident from about mid-century, Journals XXV, p. 870; Journals XXVI, pp. 74-6

is P. K. O'Brien, T. Griffiths, and P. A. Hunt (1991)
} 
tivity could be defined, our belief was that the discussion might then proceed to consider how far British society and culture were peculiarly favourable to the emergence of such a group. With regret, it has to be reported that the data available on the majority of inventors proved to be seriously incomplete, precluding any systematic prosopographical analysis. Sufficient information does, however, exist to enable us to confront many of the more durable hypotheses on the particular characteristics of the "typical» inventor.

It can, for example, be suggested that the backgrounds of inventors altered markedly over time, the change coinciding approximately with the shift towards factor-saving improvements in the third phase of innovation from the 1790s. Textbook accounts are most effective when surveying the forces and people behind technical change in this period. The «developers» and «adapters» of the nineteenth century were, for the most part, employed in the textile industry and were concerned to overcome precisely defined technological problems through modest, incremental improvements to established mechanical devices. The «inventors» and «discoverers» of the eighteenth century, by contrast, appear to be altogether more Schumpeterian and, in analytical terms, interesting figures. Their aims, reconstructed from patent specifications and other contemporary data, tended to be pitched at a level which communicates a broadly-based, «pre-professional» interest in the potential inherent in new technologies. Perhaps reflecting this, eighteenth-century inventors emanated in far larger proportions, relative to their nineteenth-century successors, from occupations and locations at some remove from the industries and districts which were intended to benefit from their ideas.

What is more, the community of "discoverers" was distributed across the mainstream class and status categories of eighteenth-century British society. It comes as no surprise, in this period, to find an Oxbridge-educated Anglican clergyman, Edmund Cartwright, absorbed by the problems of powered weaving and mechanical wool-combing ${ }^{35}$. Examples can be cited to the contrary, but the «typical» inventor in the classical age of invention should no longer be depicted as an «artisan», on the fringes of the established social order. Whatever validity that interpretation has relates much more to the later period of adaptation and improvement ${ }^{36}$.

"M. Strickland (1843); P. K. O'Brien (forthcoming, 1997).

3n This conclusion derives from a prosopographical analysis of textile inventors in the period, 1660.1850, available from the Director of the Institute of Historical Research, Senate House, Malet Street, London WCIE 7HIU. Information on the occupations of patentees comes from Woodcroft (1854), divided into status categories using the classifications adopted by $K$. Honeyman (1982) and F. Crouzet (1985). 
The evidence also indicates that the majority of «discoverers» adhered to the Anglican faith. The Dissenters, who figure so prominently in Weberianderived accounts which locate Britain's technological leadership in religious diversity, are not represented out of proportion to their small and declining share of the nation's literate population in the eighteenth century. Where their names appear most frequently, as in the midland textile area, it is in regions with large concentrations of nonconformists in their urban communities. Furthermore, there appears to have been little of economic utility either in the religious beliefs or in the upbringing and education of eighteenth-century Dissenters ${ }^{3 i}$. Anglican theology placed just as much emphasis on the virtues of innovation and hard work in business, while the dissenting academies, given such prominence in the literature, offered mostly conventional, broad-based curricula, with little weight given to vocational instruction. Few eighteenthcentury innovators received an education that might have fed directly into their subsequent work on the frontier of technology ${ }^{38}$.

At most, a handful of «discoverers» attended university in either England or Scotland. Some were drawn thereby into networks, both local and international, for the exchange of scientific information on the bleaching and dyeing of cloth. The connexion between science and formal education on the one hand and the finishing of cloth on the other is well documented. Indeed, throughout the eighteenth century, innovations in bleaching, dyeing and printing owed much to knowledge and expertise brought to Britain from the Near East, France and Holland ${ }^{39}$.

At the same time, numerous channels of education and communication, both formal and informal, developed across Britain. These, it has been argued, contributed to the development of a culture favourable to innovation. Newspapers, magazines, pamphlets, books, in addition to lectures and exhibitions of toys, models and automata proliferated over polite, urban society, promoting a broader appreciation of the principles of natural philosophy (science) and technology (mechanics) ${ }^{40}$. Scientific societies, in which debate occasionally but not invariably centred on matters pertaining to industry, emerged in many

17. M. Watts (1978), pp. 287.9, 350-3; E. D. Jebb (1935), pp. 45, 57, 92.3, 112.32; A. D. Gil. bere (1976), pp. 14-108.

F" H. McLachlan (1931), pp. 6-15, 43.4; R. S. Mortimer (1947), pp. 66-70; A. G. Matthews and G. F. Nuttall (1933-5), pp. 337-8; A. P. F. Sell (1992). For Anglicanism and attitudes to innovation. see M. C. Jacob (1976); P. Harrison (1990).

"On bleaching, see A. E. Musson and E. Robinson (1969), pp. 274.331: S. H. Higgins (1924), pp. 73.9. (On dyeing techniques, H. Wescher (1959); (G. Schaefer (1941); Journals XLI, pp. 289 ,
467,882 .

t) P. Clark (1986); W. H. G. Armytage (1965); R. S. Porter (1980). 
towns ${ }^{41}$. In this, as in most things, London was in the vanguard. Yet the tendency of the Royal Society, founded in 1662, to overlook the practical implications of scientific investigation eventually led to the formation of the Society for the Encouragement of Arts, Manufactures and Commerce in 1754. Early in its career, this metropolitan, gentlemanly body was more active in the promotion of industrial design and the development of technology relevant to the growth of textile production than the Royal Society or, indeed, any other provincial society, including the Manchester Literary and Philosophical Society, where discussions of practical import were confined to the bleaching and dyeing of cloth ${ }^{42}$. The Society of Arts» preoccupation with import substitution, with the design of goods and with jobs for under-employed women and children complemented the work of the Linen Boards of Ireland and Scotland, founded in 1711 and 1727 respectively. Reflecting government concern to maintain social and political order across the Celtic fringe, the boards funded, largely from State revenues, the cultivation of flax, industrial training, the diffusion of machinery (mostly spinning wheels) and the diffusion of bestpractice techniques in the manufacture and bleaching of linen cloth ${ }^{+3}$.

If all may be said to have contributed to a culture broadly conducive to a spirit of "discovery", the practical implications of that culture remain difficult to specify. It is, however, surely suggestive that the emergence of more widespread interest in natural philosophy and mechanics, along with references to technological fantasies among the upper and middle ranks of British society coincided with a marked discontinuity in economic development ${ }^{+4}$. Evidence of cultural change, however impressionistic, impressed contemporaries. Samuel Johnson, himself associated with the textile technologists, Lewis Paul and John Wyatt, remarked that athe age is running after improvement. All the business of the world is to be done in a new ways ${ }^{45}$. We may speculate, even if we cannot conclusively demonstrate, that this cultural reordering helped to raise the propensity of hitherto conservative businessmen to re-evaluate risks and to search for and experiment with new ideas. The «wave of gadgets» which, to Ashton's schoolboy, signalled the onset of the Industrial Revolution, emerged from this «culture» ${ }^{\text {th. }}$.

41 Inkster (1985); Inkster (1973); Inkster (unpublished paperi; S. A. Shapin (1972).

42 D. G. C. Allan (1974); Anon. (1763); T. Thomson (1812); M. Hunter (1981); Hunter (1989);

R. A. Smith (1883), pp. 83.5; A. W. Thackrav (1974).

43 C. Gill (1925); H. D. Gribbon (1977); A. J. Durie (1979); Anon. (1727).

it C. Basalla (1988), pp. 74.7, for technological fantasies; P. G. Bouce (1980).

t5 Ashton (1948a), p. 11; Wadsworth and Mann (1931). pp. 420, 430, 445.

th Ashton (1968), p. 48; M. Thompson, R. Ellis, and A. Wildavsky (1990). 


\section{CONCLUSIONS}

Most of the prototype inventions which were to transform the manner and scale of textile production across Britain emerged in the brief span of six or seven decades encompassing the careers of John Kay and Edmund Cartwright, the latter of whom withdrew from textile innovation from 1792. The diffusion, adaptation and improvement of basic technologies from about 1790 can be ex. plained by reference to conventional demand-led and supply-induced models, derived from economic theory. Such models are relevant to the earlier phase of technological breakthroughs, as Europeans were, at most times, interested in profiting from potentially exploitable discoveries. They have, however, little to offer those seeking to construct general theories for the emergence of particular techniques, machines or products at specific points in time.

The task for historians remains to explain the dramatic rise in the number and range of inventions during the period of «discovery». In order to do so, they need to take the long view. By the mid-eighteenth century, the manufacture of textiles in general and cottons in particular had reached an advanced stage of development. That outcome owed much to a political and economic context comprising overseas trade with Asia, Africa and the Americas, the substitution of domestically-produced cottons for Indian calicoes on the home market, and the politically-sponsored development of linen production in Ireland and Scotland. The expansion of foreign markets and of raw material imports to supply the growing needs of native industries depended on a framework of mercantilist regulations enacted from London. A role might be found in this phase of technological development for a distinctively English culture of polite consumerism, as the fashion-conscious urban middle class aspired to purchase more and better cloth for personal attire and furnishings. Yet «supply-side forces», which promoted economic integration and which provided households with the real income required to increase their purchases of textiles, still seem to be the more crucial factor behind the growth of home demand.

When it comes to analysing the inventors themselves, historians, if they wish to avoid the heroic and theological language of Victorian eulogies, may be obliged to utilize that portmanteau category «culture» and to consider the implications of observations such as that of Josiah Tucker that «a strange. frenzy has infected the whole English nation" ${ }^{47}$. The harmonious integration

4 There were calls in the nineteenth century for Lancastrian poets to compose an epic of invention or "Arkw'rightiad". One appears in F. Fspinasse (1849), p. 206-7. 
of science and religion involved in the eighteenth-century culture of discovery was expressed in verse by that latitudinarian Anglican clergyman and macro inventor, the Reverend Edmund Cartwright ${ }^{48}$ :

Since even Newton owns that all he wrought

Was due to industry and patient thought

What shall restrain the impulse that I feel

To forward as I may the public weal

By his example fired to break away

In quest of truth through darkness into day.

\section{BIBLIOGRAFIA}

AlLAN, D. G. C. (1974): «The Society of Arts and Government, 1754-1800: public encouragement of the arts, manufactures and commerce in eighteenth century Englandm, Eighteenth Century Studies 7: 434-52.

Anderson, C. and Bowman, M. J. eds. (1965): Education and Economic Development. London: Cass.

ANov (1727): Plan by the Commissioners and Trustees for Improving Fisheries and Manufactures in Scotland, for the Application of their Funds. Edinburgh.

- (1763): A Concise Account of the Rise. Progress and Present State of the Society for the Encourugement of Arts, Manufactures and Commerce, Instituted at London, anno MDCCLIV by a member of the Society. London.

ANst1:, J. (1803): Observations on the Importance and Necessity of Introducing Improved Machinery into the Woollen Manufactory. n.p.

Armytage, W. H. G. (1965): «Education and Innovative ferment in England, 1588 1805m, in Anderson and Bowman (1965).

Ashto., T. S. (1948a): The Industrial Revolution, 1760-1830. London: Oxford University Press.

- (1948b): «Some Statistics of the Industrial Revolution», The Manchester School of Economic and Social Studies 16: 214-34.

- (1968): The Industrial Revolution, 1760-1830. Oxford: Oxford University Press.

BaINEs, E. (1803): Observations on Woollen Machinery. Leeds.

- 11835): History of the Cotton Manufacture. London.

Basali.A, G. (1988): The Evolution of Technology. Cambridge: Cambridge University Press.

Ben-Schacifar, A. Y. (1984): "Demand v. Supply in the Industrial Revolution: A Comment", Journal of Economic History 44: 801.5.

Bfrsi, M. and P. Hutoson (1992): «Rehabilitating the industrial revolution», Economic History Review 2nd ser. 45: 24.50.

th Strickland (1843), p. 279; O'Brien (forthcoming, 1997). 
Bilkt:R, W. E.; Hughes, T. P. and PINCH, T. J. eds. (1987): The Social Construction of Technological Systems. New Directions in the Sociology and History of Tecbnology. Cambridge, Mass.: MIT Press.

Bolc., P. G. (1980): “Aspects of sexual tolerance in eighteenth-century England», Britis J Jumal for Eighteenth Century Studies. 3: $173-92$.

BREwer, J., and PORTER, R. S. eds. (1993): Consumption and the World of Goods. London: Routledge.

Brthell, D. (1969): The Handloom Weavers. A Study in the English Cotton Industry During the Industrial Revolution. Cambridge: Cambridge University Press.

Campbe1.1., C. (1987): The Romantic Ethic and the Spirit of Modern Consumerism. Oxford: Blackwell.

Ciakx, P. (1986): Sociability and Urbanity. Clubs and Societies in the Eighteenth Century City. Leicester: Victorian Studies Centre, University of Leicester.

C.LAY, C. G. A. (1984): Economic Expansion and Social Change. England, 1500-1700. 2 vols. Cambridge: Cambridge University Press.

CoAls, A. W. (1958-9): "Changing attitudes to labour in the mid-eighteenth century", Economic History Review 2nd ser. 11: 35-51.

- (1976): "The Relief of l'overty, Attitudes to Labour, and Economic Change in England, 1660-1782», International Review of Social History 21: 98-115.

CoIEMAN, D. C. (1977): The Economy of England, 1450-1750. London: Oxford University Press.

Crarts, N. F. R. (1985): British Economic Growth During the Industrial Revolution. Oxford: Clarendon Press.

- and HARLEY, C. K. (1992): «Output growth and the British industrial revolution: a restatement of the Crafts.Harley view', Economic History Review 2nd ser. 45: 703. 30.

CRouzet, F. (1985): The First Industrialists. The Problems of Origins. Cambridge: Cambridge University Press.

Cillien, L. M. and Swout, T. C. eds. (1977): Comparative Aspects of Scottish and Irish Economic and Social History, 1600-1900. Edinburgh: John Donald.

DEANe, P. and CoLE, W. A. (1962): British Economic Growth, 1688-1959. Trends and Structure. Cambridge: Cambridge University Press.

$D_{E}$ V VIES, J. (1994): "The Industrial Revolution and the Industrious Revolution», Journal of Economic Hislory 54: 249.70.

DiNTENFASS, M. (1992): The Decline of Industrial Britain, 1870-1980. London: Routledge.

Durie, A. J. (1979): The Scottish Linen Industry in the Eighteenth Century. Edinburgh: John Donald.

Durton, H. I. (1984): The Patent System and Inventive Activity During the Industrial Revolution, 1750-1852. Manchester: Manchester University Press.

Evwarbs, M. M. (1967): The Growth of the British Cotton Trade, 1780-1815. Manchester: Manchester University Press.

EspINASsE, F. (1849): “Lancashire Industrialism (A Lecture to the Mechanics' Institution, Manchester)m, The Roscoe Magazine 1: $201-9$.

GilbFrt, A. D. (1976): Religion and Society in Industrial England. Church, Chapel and Social Change, 1740-1914. London: Longman.

Gilboy, E. (1967): «Demand as a Factor in the Industrial Revolution», In Hartwell 1967. 
Gilu., C. (1925): The Rise of the Irish Linen Industry: Oxford: Oxford University Press.

Gomme, A. A. 1932-3): "Date Corrections to English Patents, 1617-1852». Transactions of the Netecomen Society 13.

Grfoors. T. E. (1921): «The Economics of Employment in England, 1660-1713», Econsmica $1: 37.51$.

(ikibrox, H. D. (1977): "The Irish Linen Board, 1711.1828m, in Cullen and Smout (1977).

Grifithe, T; Hunt, P. A. and O'Bries, P. K. (1992): "Inventive Activity in the British Textile Industry, 1700-1800», Journal of Economic History 52: 881-906.

Grulches, Z. (1990): "Patents Statistics as Economic Indicators: A Survey». Joumal of Economic litcrature 28: 1661-1707.

HARRISON, P. (1990): «Religion» and the Religions in the English Enlightenment. Cambridge: Cambridge University Press.

Haktwili. M. ed. (1967): The Causes of the Industrial Revolution in England. London: Methuen.

Hicians, S. H. (1924): A History of Bleaching. London. Longman.

Honimax, K. (1982): Origins of Enterprise. Business Leadership in the Industrial Revolution. Manchester: Manchester University Press.

Hunson, P. (1992): The Industrial Revolution. London: Edward Arnold.

Hیxт, E. H. (1986): «Industrialization and Regional Inequality: Wages in Britain, 1760 1914». Journal of Economic Histom 46: 935-66.

- and F. W. Botham (1987): "Wages in Britain during the industrial revolution", liconomic History Review 2 nd ser. 40: 380-99.

Huxtr. M. (1981): Science and Socity in Restoration England. Cambridge: Cambridge University Press.

—_ (1989): Estublishing the New Science. The Experience of the Early Royal Soctety. Wood. bridge: Boydell.

Hutchisox, T. W. (1988): Before Adam Smith. The Emergence of Political Economy, 16621776. Oxford: Blackwell.

INKSTER, I. (1973): "The development of a scientific community in Sheffield, 1790-1850: a network of people and interests». Transactions of the Hunter Archaeological Society 10: 99.131 .

— ed. (1985): The Steam Intellect Societies. Essays on Culture, Education and Industry circa 1820-1914. Nottingham: Department of Adult Education, University of Nottingham.

Inkster, I. (1991): Science and Technology in History. An Approach to Industrial Development. Basingstoke: Macmillan.

- Unpublished Paper. The Provincial Context of Industrial Revolution: science and society in Derby, 1730-1830. Available from the author, Faculty of Humanities, Department of International Studies, Nottingham TRent University.

JACOB, M. C. (1976): The Newtonians and the English Revolution, 1689-1720. Hassocks: Harvester Press.

JAMIESON, D. R. (1969): «Introduction», in Woodcroft (1969).

JЕвB, E. D. (1935): Nonconformity and Social and Economic Life, 1660-1800. London.

Journals: Joumals of the House of Commons. London.

KrrRixie, E. (1985): Textile Manufactures in Early Modern England. Manchester: Manchester University Press. 
Landis, D. S. (1969): The Unbound Prometheus. Technological Change and Industrial Development in Western Lurope from 1750 to the Present. Cambridge: Cambridge University Press.

Lf.MIRE, B. (1991): Fashion's Favourile. The Collon Trade and the Consumer in Britain, 16601800. Oxford: Oxford University Press.

Ma(ifon, C. (1988): Inventing the Industrial Revolution. The English Patent System, 16601800. Cambridge: Cambridge University Press.

Mantos: $\mathrm{P}$. (1964): The Industrial Revolution in the Eighteentb Century. An Outline of the Beginnings of the Modern Factory System in England. London: Methuen.

Mathias, P. and Davis, J. A. eds. (1991): Innovation and Technologv in Europe from the Eighteenth Century to the Present Day. Oxford: Blackwell.

MatThew' A. G. and NutTall, G. F. (1933-5): «The Literary Interests of Non-conformists in the 18th Century", Transactions of the Congregationalists Historical Socicty 12:337.8.

MiKendrick, N. Brewer, J. and Plicma, J. H. (1982): The Birth of a Consumer Society. The Commercialization of Eighteenth-Century England. London. Europa.

MeLachlan, H. (1931): English Fducation under the Test Acts. The Histon of the Non conformist Academies, 1662-1820. London.

Mokyr, J. (1987): «Demand v. Supply in the Industrial Revolution», Journal of Economic Hisiony 37: $981 \cdot 1008$.

MokYR, J. (1990): The Lever of Riches: Technological Creativity and Economic Progress. New York and Oxford: Oxford University Press.

Mortiner, R. S. (1947): "Quaker Education", Journal of the Friends» Historical Society 39: 66.70.

Mukeril, C. (1983): From Graven Images. Patterns of Modern Materialism. New York: Columbia University Press.

Misson, A. E. and Robinson. E. (1969): Science and Technology in the Industrial Revolution. Manchester: Manchester University Press.

National Bureal of Economic: Research, New York (1962): The Rate and Direction of Inventive Activity: Economic and Social Factors. A Conference of the Universitics-National Burcau Commiltee for Economic Research and the Committee on Economic Grouth of the Social Science Research Council. Princeton: Princeton University Press.

O'Brit:s, P. K. (1985): «Agriculture and the Home Market for English Industry, 16601820», English Historical Review 100: 773-99.

- 1991): «The mainsprings of technological progress in western Europe, 1750$1850 \%$, in Mathias and Davis (1991).

- (1993): «Introduction: Modern conceptions of the industrial revolution", in O'Brien and Quinault (1993).

- (Forthcoming 1997): «Biographical Narratives and Theories of Technological Discovery: the case of the Reverend Edmund Cartwright: Inventor Extraordinaire», To be published in Textile History.

- and KeyDER, C. (1978): Economic Growth in Britain and France, 1780-1914. Two Paths to the Twentieth Century. London: Allen and Unwin.

- Griffitus, T. and Hunt, P. (1991): «Political components of the Industrial Revolution: Parliament and the English cotton textile industry, 1660.1774m, Economic History Review 2 nd ser. 44: 394.423.

- - and - (1995): "There Is Nothing Outside The Text, and There Is No Safety In Numbers: A Reply to Sullivan», Journal of Economic History 55: 671-2. 
and QiiNalli, R. eds. (1993): The industrial Revolution and British Society. Cambridge: Cambridge University Press.

PatiNit, A. (1986): alohn Kay's Flying Shuttle: some consideration on its technical ca. pacity and cconomic impacts, Textile History 17: 149-66.

Porter, R. S. (1980): aScience, provincial culture and public opinion in Enlightened England", British Journal for Eighteenth Century Studies 3: 20.46.

RICHARDS, E. (1974): «Women in the British Economy since about 1700: an interpretation», History 59: 337-57.

Rose, M. B. ed. (1996): The Lancashire Cotton Industry. A History since 1700. Preston: Lancashire County Books.

RosenberG, N. (1982): Inside the Black Box. Technology and Economics. Cambridge: Cam. bridge University Press.

SAMUFL, R. (1977): «Workshop of the world: steam power and hand technology in midVictorian Britain", History Workshop a journal of socialist bistorians 3: 6-72.

Simaffre, (i. (1941): «The History of Turkey Red Dyeing», Ciba Review no. 39: 1407. 16.

Schmooklt.k. J. (1962): “Comment on Barkev S. Sanders, 'Some Difficulties in Measuring Inventive Activity's, in National Bureau of Economic Research. (1966): Invention and Economic Grouth. Cambridge, Mass.: Harvard University Press.

Srll, A. P. F. (1992): "Philosophy in the Eighteenth-Century Dissenting Academies of England and Wales", History of Universities 11:75.122.

Shammas, C. (1990): The Pre-industrial Consumer in England and America. Oxford: Clarendon Press.

Shapis, S. A. (1972): «The Pottery Philosophical Society, 1819.1835: an examination of the cultural uses of provincial sciencen, Science Studies 2: $311-36$.

Singer, C.; Holmyard, E. J.; Hall, A. R. and Williams, T. I. eds. (1957): A History of Technology. Vol. III. From the Renatssance to the Industrial Revolution, c. 1500-c. 1750. Oxford: Clarendon Press.

- $-\ldots, \ldots$ and - - eds. (1988): A History of Technologv. Vol. IV. The Industrial Revolution, c. 1750-c. 1880. Oxford: Clarendon Press.

SMith, R. A. (1883): A Centenary of Science in Manchester for the Hundredth Year of the Literary and Pbilosophical Society of Manchester). London.

Sokolofr, K. L. (1988): «Inventive Activity in Early Industrial America: Evidence from Patent Records, 1790-1846», Journal of Economic History 48: 813-50.

Solow, B. (1991): «Introduction», in Solow (1991).

- ed. (1991): Stavery and the Rise of the Atluntic System. Cambridge: Cambridge University Press.

STRICKLAND, M. (1843): A Memoir of the Lite and Writings and Mechanical Inventions of Ed mund Carturight, D. D., F. R. S., Inventor of the Power Loom etc. London.

SUlLIVAN, R. J. (1989): «England's 'Age of Invention': the acceleration of patents and patentable invention during the Industrial Revolution», Explorations in Economic Hislory $26: 424.52$.

- (1990): «The Revolution of Ideas: Widespread Patenting and Invention during the English Industrial Revolution", Journal of Economic History 50: 349.62.

- (1995): «Patent Counts and Textile Invention: A Comment on Griffiths, Hunt and O'Brien», Journal of Economic History 55: 666-70. 
Sitcilfff, T. (1843): An Exposition of the Facts Relating to the Rise and Progress of the Woollen, Linen and Cotton Manufactures of Great Britain. Manchester.

TuAckkay, $\Lambda$. W. (1974): «Natural knowledge in cultural context: the Manchester model», American Historical Revieu: 89: 672-709.

'Lhompson, M.; Elis, R. and Wilonisky, A. (1990): Cultural Theom: Boulder, Colorado and Oxford: Westriew.

Thomson, T. (1812): History of the Royal Society from its Institution to the End of the Eighte'nth Century. London.

Timmins, G. (1996): "Technological Change", in Rose (1996).

WadsworTH, A. P. and MANi, J. de L. (1931): The Cotton Trade and Industrial Lancashirc, 1600-1780. Manchester: Manchester University Press.

Watrs, M. R. (1978): The Dissenters. I. From the Reformation to the French Revolution. Oxford: Clarendon Press.

Wescher, H. (1959): «Turkey Red Dycing», Ciha Revieu 12, no. 135: 21-6.

W'o(), Sir H. T. (1911-12): «The Inventions of John Kay, 1704-70», Journal of the Roval Society of Arfs 60: 73.86 .

Wood:korT, B. (1854): Tilles of Patents of Invention. Chronologically Arranged from March 2, 1617 (14 James 1 ) to October 1, 1852 (16 Victoriac). 2 vols. London.

- (1969): Alphabetical Index of Patentees of Inventions. 1st ed. 1854. Reprinted 1969. London. 